\title{
低温地下タンクの施工方法と熱的諸問題
}

\section{CONSTRUCTION METHOD AND VARIOUS THERMAL PROBLEMS FOR UNDERGROUND STORAGE TANK FOR CRYOGENIC LIQUEFIED GAS}

\author{
秋田好雄*1 ・小林昭夫*2 ・西川秀樹*3 ・柳 沢一郎*4 ・瀬戸正幸*5 \\ By Yoshio Akita, Akio Kobayashi, Hideki Nishikawa, Ichiro Yanagisawa and Masayuki Seto
}

\section{1. 緒}

著者らは約 10 年前から地下タンクに関する基礎的研 究(1),2),3)を重社コンポジットセグメントを利用した低温 液体貯蔵用地下タンクの研究を行なってきた。そしてこ のたび東京豊洲地区に低温 LPG 貯蔵用コンポジットセ グメント製地下タンクをウェルポイントとセグメントエ 法を併用して構筑し低温液体プロパン (LPG) を貯蔵し 各種の計測を行なった。この実験によって臨海埋立地の 悪条件地域でも低温液化ガス貯蔵用地下タンクの建設が 可能であることが判明した。

\section{2. 実験の目的}

わが国では地下タンクを建設する場所は臨海工業地帯 が多いので，土質が悪く，地盤が軟弱で，地下水位が高 く, 地下の掘削拉よび建設工事が困難である。したがっ て欧米その他で行なわれている従来の工法を採用すると 地下タンクの信頼性が懸念される場合があり, さらに工 事は地上タンクより困難で，また作業面積が制限される 場合が多い。

本研究の第一の目的はウェルポイントとセグメント工 法の併用方法が臨海工業地帯の軟弱地盤で地下タンクを 構筑する場合に適しているか否か検討することであっ た。これらの施工法のほかに低温の液体を地下タンクに 貯蔵することにより生ずる熱現象による問題すなわち冷 却初期の熱応力とタンクの強度, 冷却速度と液体の蒸発 量, 凍結深度, 凍結土圧および凍上などがあげられる。 著者らはこれまでに熱現象に伴ら問題を解明するため に, 小型模型実験々理論解析を行なってきたが,この理

\begin{tabular}{|c|c|}
\hline *1 工博 & 日本海事協会理事 \\
\hline$*_{2}$ & 石川島播磨重工業株式会社部長 \\
\hline$* 3$ & 同 次長 \\
\hline *4 正会員 & 研究員 \\
\hline$* 5$ & 東京ガス株式会社次長 \\
\hline
\end{tabular}

論解析が LPG 地下タンクにも適用できるか否か検討 し, 大型低温地下タンクの熱現象を定量的に推定するこ とが第二の目的であった。

なお本実験では短期間に熱現象を把握するために，使 用したセグメントに断熱材を取付けずに行なった。

\section{3. コンポジットセグメント製地下タンクの 構築}

\section{（1）地下タンク構築場所の土質調査}

地下タンクの設計, 構築に先立ち構築場所の土質調查 を行なった。結果は表一1，表一2, 図一1に示す。ボー リングはタンク中心について G.L. $-8.8 \mathrm{~m}$ まで行なっ たが，土質はシルトで貫入抵抗は 0 , 飽和度 $100 \%$ の軟 弱地盤であった。

\section{（2）セグメントエ法による地下タンクの構筑}

$20 \mathrm{~m}^{3} \mathrm{LPG}$ 地下タンクとこれに用いたコンポジット セグメントを図一2，図一3に示す。コンポジットセグ メントの詳細については文献 1) を参照。

構築場所として東京ガス (株) 豊洲工場が選ばれた。 豊洲工場の液化プロパン地上タンクより配管により低温 LPG を地下タンクに入れ，気化した LPG は戻り管に て地上タンク頂部に戻し入れる。液は地上タンクと地下 タンクの落差にて導くこと, 液配管での入熱を少なくす るために, 地下タンクは地上タンクの至近に設置するこ とが有利と考えられ，その結果地上タンク防液堤外で地 上タンクに最も近い位置に地下タンクを設置することに した。地下タンク構筑にあたって次の制約と問題点があ った。すなわち地上タンクに近いためガス切断, 電気溶 接等の火気の使用がいっさい禁止されたことと地下タン ク構筑場所の土質がシルトであり, 地下水位が高いため 掘削が困難であったことである。前者については後述す るように防水剂と接着材を使用することし，後者につい 
表一1 土 質 調 查 表

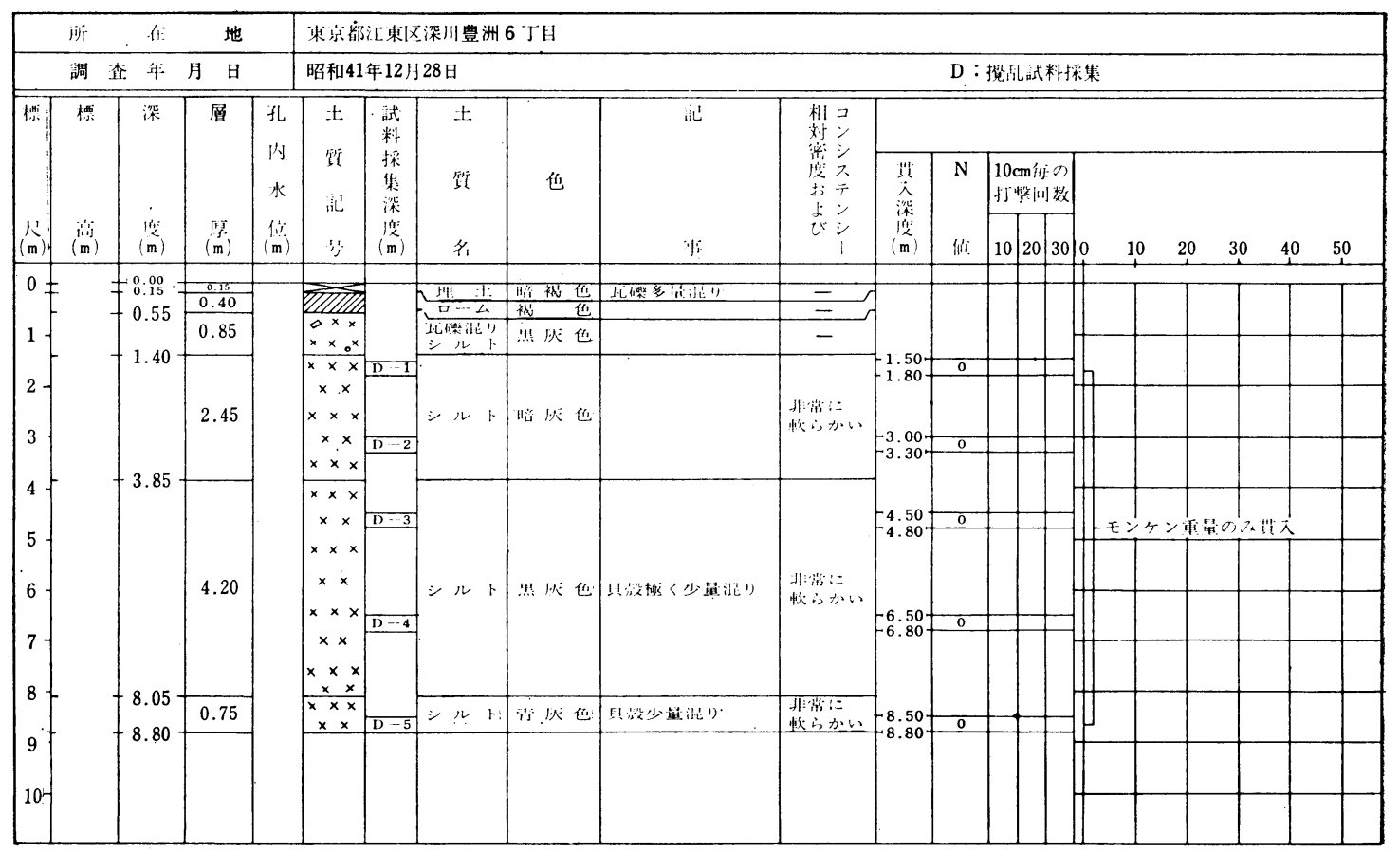

表一2 土質試験結果

\begin{tabular}{|c|c|c|c|c|c|}
\hline at it if & $\mathrm{D}-1$ & $\mathrm{D}-2$ & D -3 & $1)-4$ & $\mathrm{D}-5$ \\
\hline fi. 4 is in $(\mathrm{m})$ & $1.50-1.80$ & $3.00-3.30$ & $4.50-4.80$ & $6.50 \sim 6.80$ & $8.50 \sim 8.80$ \\
\hline A. si $4(y-2)$ & シ. F & En: & 洋卜 & $\therefore \approx r$ & 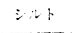 \\
\hline 40 thit $\left(t / m^{3}\right)$ & 1.550 & 1.620 & 1.553 & 1.560 & 1.685 \\
\hline 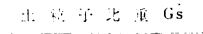 & 2.731 & 2.865 & 2.880 & 2.840 & 2.790 \\
\hline 保尖 it $W(a)$ & .78 .3 & 69.1 & 83.9 & 77.4 & 57.4 \\
\hline 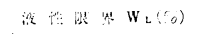 & 75.5 & 70.9 & 80.5 & 77.3 & 62.0 \\
\hline 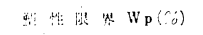 & 34.6 & 31.5 & 35.5 & 31.7 & 26.0 \\
\hline 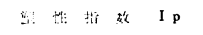 & 40.9 & 39.4 & 45.0 & 45.6 & 36.0 \\
\hline (io) & 20.0 & 0 & 0 & 0.7 & 0 \\
\hline 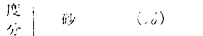 & 8.0 & 10.0 & 7.0 & 18.9 & 8.0 \\
\hline \begin{tabular}{l|l}
$f 1$ & In? \\
on
\end{tabular} & 43.8 & 56.0 & 54.8 & 20.4 & 48.0 \\
\hline 粼i: $(50)$ & 28.2 & 34.0 & 38.2 & 60.0 & 44.0 \\
\hline 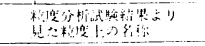 & 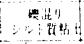 & 20 thes & *ili : : & 料 $\quad$ t: & 将: \\
\hline 間 隌 此 $\mathrm{C}$ 。 & 2.142 & 1.998 & 2.415 & 2.228 & 1.606 \\
\hline 能和 & 99.6 & 99.2 & 100.0 & 98.7 & 103.0 \\
\hline
\end{tabular}

てはウェルポイントにより地下水位を下げた。しかし土 質がシルトのため地下水位が十分に下がらず底部の施工 は困難であり掘削土の崩壊が著しく, セグメント裹部に 空洞が生じたので, 裹込めを行なった。以下, 地下タン クの構筑を施工の順序に従って説明する。

a) ウェルポイントの設置

土質調查の結果, 地下水位は G.L. $-0.5 \mathrm{~m}$ と高い ため, ウェルポイントにより地下水位を下げることにし た。土質がシルトのためウェルポイントの効果が少な く, G.L. $-4.5 \mathrm{~m}$ 近辺までしか低下せず底板の施工時

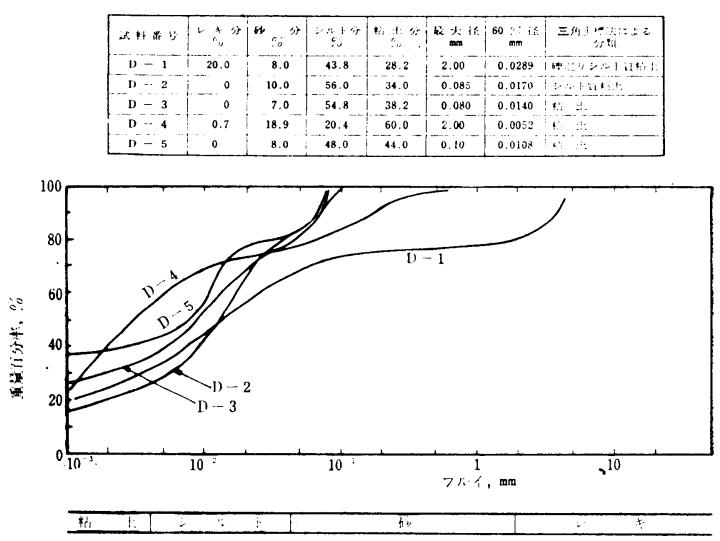

図-1 粒径加積曲線

の排水は釜場からバキュームポンプを用いて直接行なわ れた。

b）上部掘削および第 1 リング組立

タンクの上面は G.L. $-1.0 \mathrm{~m}$ に位置するため, まず G.L. $-1.0 \mathrm{~m}$ まで掘削し, 掘削範囲はタンク中心から 半径 $2.5 \mathrm{~m}$ とした。タンク外径周囲には鍔部コンクリ 一トが施工されるので, 捨コンクリートを打設した。次 に第 1 リング部分の掘削が行なわれた。この掘削はタン ク外径の範囲のみでよく, 掘削された内部に第 1 段セグ メントを据付けた（写真一1 参照)。

c）鍔部コンクリートの施工

第 1 段セグメント据付けを完了したら，第 1 段セグメ 

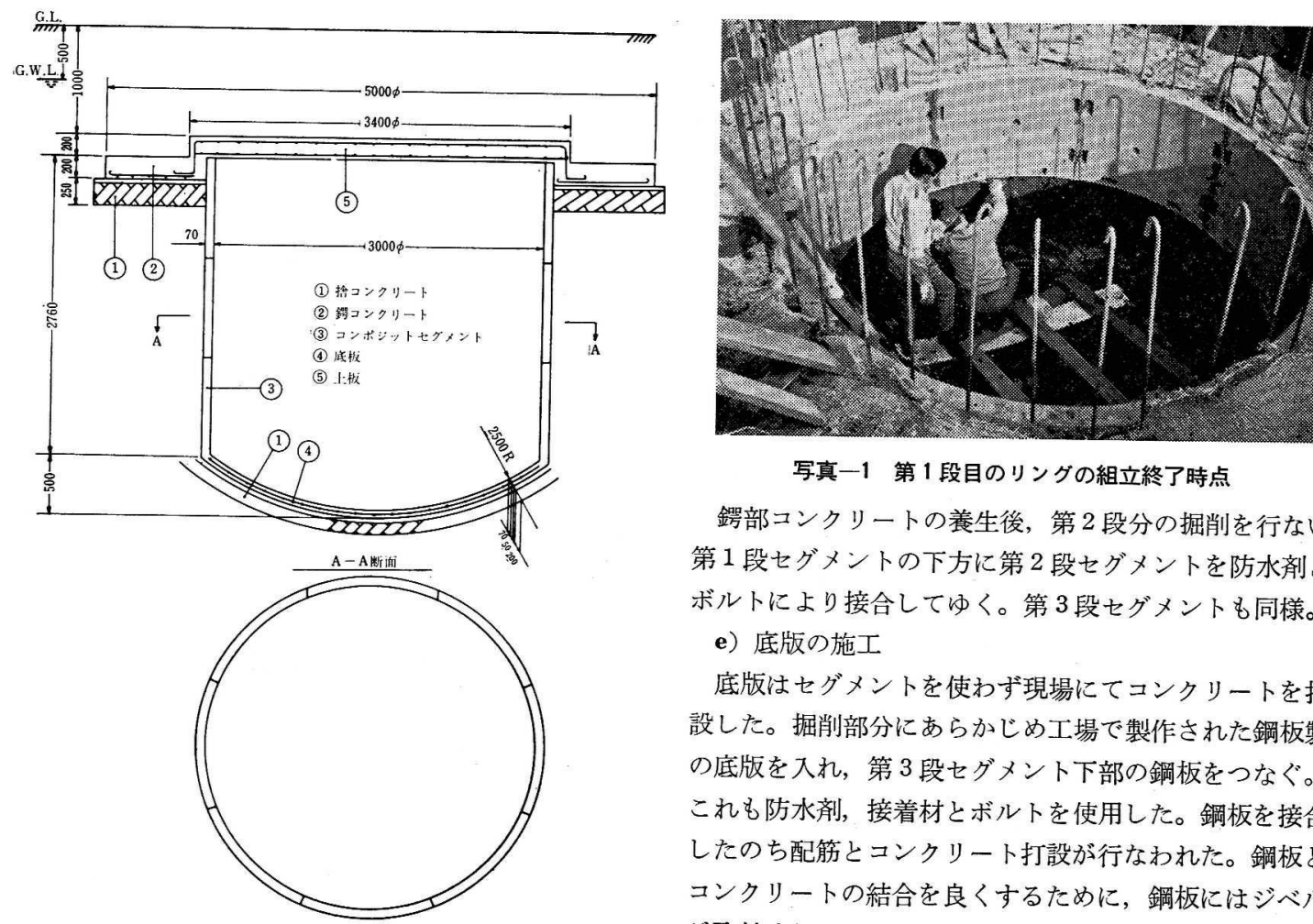

写真一1 第 1 段目のリングの組立終了時点

鍔部コンクリートの養生後, 第 2 段分の掘削を行ない 第 1 段セグメントの下方に第 2 段セグメントを防水剤と ボルトにより接合してゅく。第 3 段セグメントも同様。

e) 底版の施工

底版はセグメントを使わず現場にてコンクリートを打 設した。掘削部分にあらかじめ工場で製作された鋼板製 の底版を入れ，第 3 段セグメント下部の鋼板をつなぐ。 これも防水剂，接着材とボルトを使用した。鋼板を接合 したのち配筋とコンクリート打設が行なわれた。鋼板と コンクリートの結合を良くするために，鋼板にはジベル が取付けられた。底部付近では水が下がらず，コンクリ 一ト打設時止水に急結セメントを一部使用した。

f）セグメント継手部の補強

セグメントは防水剂とボルトにて接合したが，内側鋼 板が不連続であるので，この閒に鋼板で添板をした。ま た防水剤は LPG に対して融溶性であるため継目はエポ キシ樹脂で覆った。タンク内側は全面エポキシ塗装を 2 回行なった。

g）上版の施工

底版が完成すると支保工を仮設し，鋼板製上版をのせ 配笳する。鉄筋は鍔部コンクリートからあらかじめ埋込 んだ鉄筋と結合することにより上版と鍔部コンクリート を一体とした。コンクリート打設, 養生後支保工をはず し上版は完成した。

h) 裹 込 め

掘削部分とセグメントとの間に生じたすき間は通常グ ラウトにより充填するが，今回は土砂の崩壊が激しくか なり大きな空洞ができたため，土砂を直接タンク外部よ り埋戻した。以上でタンク本体は完成され上部土砂は配 管後埋启した。

\section{4.コンポジットセグメントに用いられる 材料の低温特性}

ートが全セグメントを吊ることになる。

d）第 2 段，第 3 段七グメントの据付け

実験用 LPG 地下タンクの内張鋼板には SS-41, $t=$ 
$2.3 \mathrm{~mm}$ を使用したので，この材料の低温特性並びに地 下タンクの水密性を維持するのに用いた防水剤と添板を セグメントに接着するためのエポキシ系接着材の低温強 度について述べる。

\section{（1） SS-41 内張薄銅板の低温特性}

a）使用時に生ずると想定される引張応力

内張鋼板に生ずる引張応力として考慮すべき応力は, LPG 注入開始時の不均一温度分布による熱応力である。 しかし LPG の液は徐々に注入されるから薄肉の内張鋼 板は周囲およびコンクリート部の熱を吸収しながらゆる やかに泠却される。したがって鋼板のある小範囲のみが 瞬間的に LPG の液の温度にまで急冷されて局部的に熱 応力を生ずることは考えられない。もし仮りにある局部 領域のみが常温から $-43^{\circ} \mathrm{C}$ に急冷され周辺が完全に固 定されているような最も苛酷な条件を考えても熱応力は 約 $13 \mathrm{~kg} / \mathrm{mm}^{2}$ となり軟鋼板の公称降伏点 $23 \mathrm{~kg} / \mathrm{mm}^{2}$ にくらべて十分に小さい応力である。

\section{b）薄肉軟鋼板の低温強度}

鋼板は低温になると降伏点も引張強度もともに上昇 する。もし鋭い切欠が存在する場合を想定すると厚肉の 鋼板では低温において脆性破壊を起こす危険性がある。 しかし以下に示すように薄板になれば切欠じん性は大幅 に向上するため脆性破壊の危険性はない。 SS-41, $t=$ $3.2 \mathrm{~mm}$ の鋼板にきわめて苛酷な人工切久をつけた試験 片を用いて低温で引張試験(Deep Notch 試験)を行なっ た結果は 図一4に示すとおりで, $-73^{\circ} \mathrm{C}$ においても公 称引張強度以上の值を示した。また遷移温度も $-100^{\circ} \mathrm{C}$ 以下と推定される。

文献 3) によると $-73^{\circ} \mathrm{C}$ 付近までの温度ではシャル ピー試験の吸収エネルギーは温度に関係せずほとんど一 定であって破面はすべて延性破面である。また文献 2) に記述されているように鋼板は板厚が薄くなるにつれて 切久じん性は向上する。したがって $t=2.3 \sim 3.2 \mathrm{~mm}$ の SS-41 鋼板は $-43^{\circ} \mathrm{C}$ において脆性破壊を起こすこと はないといえる。

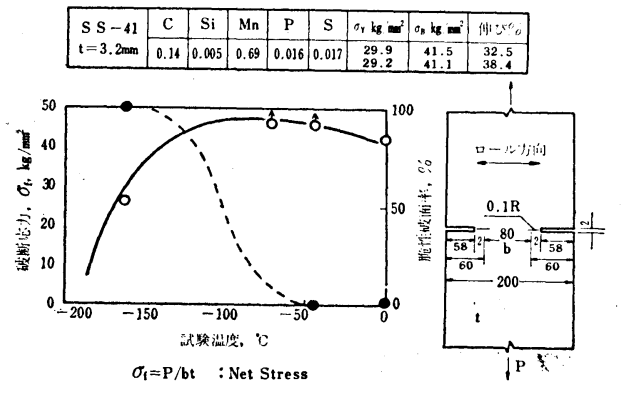

图-4 SS-41 莎板の Deep Notch 試験結果

\section{（2）エポキシ系接着材および防水剤の低温特性}

通常セグメント同志の接合には水密保持のためにボル トと溶接を用いる。しかしこの実験タンクでは火気を使 用することはできなかったので，溶接の代りに防水剂と エポキシ系接着材を用いた。そこで防水剂およびエポキ シ系接着材の低温特性について各種実験を行なって次の 結論を得た。すなわち常温において $250 \%$ 以上の伸びと $50 \mathrm{~kg} / \mathrm{cm}^{2}$ の引張強度をもつ防水剂は $-45^{\circ} \mathrm{C}$ の低温に すると強度は $215 \mathrm{~kg} / \mathrm{cm}^{2}$ と増加し伸びは $27 \%$ と低下す るが，軟鋼の低温における伸びに比較して同程度なので

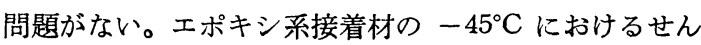
断強度は約 $100 \mathrm{~kg} / \mathrm{cm}^{2}$ であった。ただしエポキシ系接 着材は曲げおよび衝撃にきわめて弱いことがわかった。

\section{LPG 地下タンクの冷却実験}

\section{（1）実験方法}

地下タンクおよび地上配管工事が終了し，空気および 窒素パージが終了したときから LPG の液が地下タンク 一注入されて冷却実験が始まる。最初の計画ではクール ダウンに要する時間を 7 日間に予定していたが，実際に は受入れラインのバルブの調整ができなかったために， 地下タンクの LPG の液が所定の液位の $2820 \mathrm{~mm}$ に 62 時間という短時間で達した。これは非常に苛酷な徐 泠条件であった。いったん LPG の液が所定の $2820 \mathrm{~mm}$ の液位に達すれば LPG の受入れを止め, 地下タンクの 液が蒸発によって $2700 \mathrm{~mm}$ まで下がると, また液位が $2820 \mathrm{~mm}$ になるまで受入れを続ける。このようなサイ クルを約 2200 時間絽返しながら約 3000 時間まで各種 計測を行なった。液位の $2700 \mathrm{~mm}$ と $2820 \mathrm{~mm}$ という 値は地下タンクの LPG 液の量がタンク容量の $80 \%$ と 85\% に相当するものである。

\section{（2）実験結果}

LPG を地下タンクに注入してから 3000 時間まで測 定した液位, 蒸発量, 凍上, 凍結深度等の測定值を図一 5 にまとめて示す。液は 62 時間で所定の液位の 2820 $\mathrm{mm}$ に達し, その後 $2820 \mathrm{~mm}$ と $2700 \mathrm{~mm}$ の間に液 位を保持したが, 途中地上タンクの液位が低くなりすぎ て, 最初の配管のままでは地下タンクに液を供給するこ とができなくなり，やむをえず 8 日間くらい配管改造工 事のため液の受入れを中止したことがあった。このため 液位が $1950 \mathrm{~mm}$ ぐらいまでに下った。このほかに LPG 船が入船したため液の受入れを中止したことが 2 度あっ た。地下タンクへの液の供給は 2200 時間で停止し,そ 


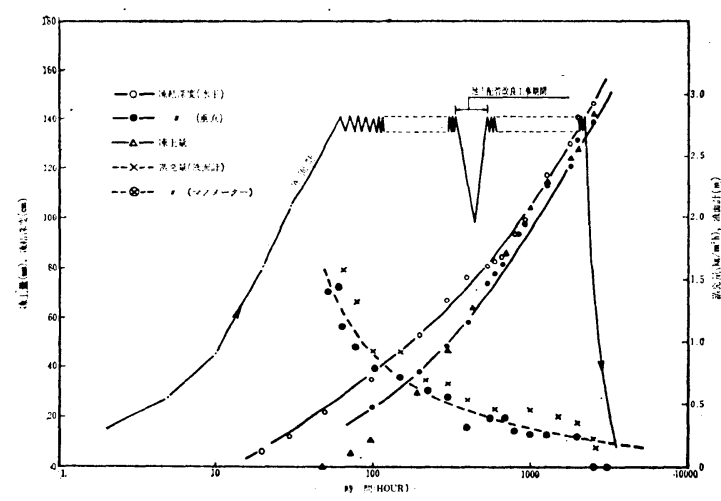

図一5 $20 \mathrm{~m}^{8} \quad$ LPG 地下タンク実験結果

の後は自然蒸発により液位を次第に減少させた。

a）地下タンクの液の蒸発量

液が所定の液位の $2820 \mathrm{~mm}$ に達する直前までは地下 タンク内の窒素パージを兼ねさせたため気化したプロパ ンは大気中に放出していたのでマノメーターでの測定は できなかった。液位が最大になる頃最大約 $1.6 \mathrm{~kg} / \mathrm{m}^{2} \mathrm{~h}$ の蒸発量が測定されたが，その後時間の経過とともに次 第に減少し受入れを停止した 2200 時間のときには 0.2 $\mathrm{kg} / \mathrm{m}^{2} \mathrm{~h}$ となった。 2200 時間以後は急に 0 に落ちてい るが，実際には LPG 蒸発しており，地下タンクの液 位の变化から逆算すると $0.2 \mathrm{~kg} / \mathrm{m}^{2} \mathrm{~h}$ 程度は蒸発してい るはずである。蒸発量の測定結果は実験前に予想した計 算值とほぼ一致している。クールダウンの終り頃の最大 蒸発量は $1.6 \mathrm{~kg} / \mathrm{m}^{2} \mathrm{~h}$ で非常に大きな值であるが，この ことは前に説明したように熱現象を短期間に把握するた めに断熱材を付けなかったためで，実際のタンクには断 熱材を付けるのでこの值よりはるかに小さくなる。

b) 凍結梁度

タンクの水平方向の凍結深度の方が垂直方向のそれよ りも多少大きく測定され 2500 時間でそれぞれ $146 \mathrm{~cm}$ と $138 \mathrm{~cm}$ の凍結深度が記録された。あとで詳述するが 凍結深度の測定值は計算値とかなり良い一致を示してい る(図一10 参照)。凍結深度に方向性があるのはタンク の底面積と側面積が異なって側面積の方が広く，ここを 通って流れる総熱量が多いためと, 側面と底面の形状の 相違によるものとが考えられる。

\section{c) 凍上}

軟弱地盤で地下水位が高いという不利な立地条件をも つわが国の臨海工業地帯においては, どの程度の凍上量 を示すかを調べるために，地下タンクの構築に際しては 全然凍上防止対策を施さずほとんど自然の状態で実験を 行なった。ただしこのタンクは完全に地下に埋設されて いるために，蓋の上の土および本体と LPG の液の自重 淁合わせると約 $0.01 \mathrm{~kg} / \mathrm{cm}^{2}$ の上載荷重がかかってい
たことになる。その結果 2500 時間で約 $140 \mathrm{~mm}$ の凍 上を起こし, 凍上率 (凍結深度に対するその方向の凍上 量の割合の百分率) は 10\% であった。タンク周辺の地 表面には多少地割れができたが，肉眼で認められるほど 地表面は盛り上がらなかった。この実験のように地盤は シルト質で，しかも地下水位が $-0.5 \mathrm{~m}$ という最悪の 土質条件で，しかも凍上防止対策を全然施さなかったに むかかわらず $140 \mathrm{~mm}$ しか凍上しなかったので，実際の タンクのときは断熱材を取付けたり簡単な凍上防止対策 を施せば凍上量はもっ上少なくなる。この実験では 3000 時間まで測定を行なったが, これ以後は凍上量の増加の 割合は次第に減少し，次の理論的考察で述べるように大 型タンクに相似則を適用すると， 10 万 $\mathrm{m}^{3}$ のタンクに おいては 3000 時間は 70 100 年に相当することにな り，この測定結果は大型タンクにも十分適用できるもの と判断して実験を打ち切った。

d) 凍結土圧

地下タンクの構築に伴う問験点の一つに凍結土圧があ る。そこで $-43^{\circ} \mathrm{C}$ という低温で測定可能な低温用土圧 計を試作して実験タンクの外壁にとりつけて計測した結 果, いちばん低温特性のすぐれた土圧計に示された值は 2500 時間で $0.1 \sim 0.2 \mathrm{~kg} / \mathrm{cm}^{2}$ であった。この值は土圧 計の誤差内に入ってしまうほどの微少のもので, 凍結土 圧は全然タンクにかからなかったものと考えてもよさそ うである。これは $N$ 值が 0 という軟弱地盤が幸いして いるのかもしれない。すなわち凍土に体積膨張が生じて も凍土のまわりの未凍結土が軟弱なため, 未凍結土は圧 縮されて変位するだけで, その反力をタンクに与えるこ とができなかったものと推定される。

\section{6. 理論的考察および大型地下タンクへの適用}

蒸発量, 熱応力, 凍結深度, 凍上等の熱現象を理論的 に解析するためには, 各部材の温度分布を求めることが 先決問題になってくる。そこで各部材の温度分布を求 め, この温度分布から蒸発量, 熱応力, 凍結深度, 凍上 等を理論的に解析する方法を述べ実験值と比較する。ま たこれらの計算値を大型の低温地下タンクに適用した結 果を述べる。

なお, この近似計算方法は冷却開始初期の非定常状態 の熱的現象を定量的に推定することを目的としているの で, 定常状態の近傍またはそれ以後の時点の定量的な推 定には不合理なことも生ずると思われる。

\section{(1) 理論的考察}

著者らは文献 2) で地下タンクの各部材が図一6 のよ うに平板の 2 層から構成されているものと仮定し, タン 

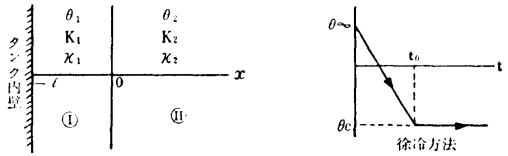

図一6 計 算モデル

ク内壁は $t_{0}$ 時間で地中平均温度 $\left(\theta_{\infty}\right)$ から液温 $\left(\theta_{c}\right)$ ま で直線的に冷却され，その後は液温で一定に維持され， 土の熱的性質は凍結することによって変化しないものと 仮定した場合の熱伝導の理論的解析を行なった。ここに

$K_{1}, K_{2}$ : 各部材の熱伝導率 $\left(\mathrm{kcal} / \mathrm{mh}^{\circ} \mathrm{C}\right)$

$\kappa_{1}, \kappa_{2}:$ 各部材の温度伝導率 $\left(\mathrm{m}^{2} / \mathrm{h}\right)$

$\theta_{1}, \theta_{2}:$ 各部材の温度 $\left({ }^{\circ} \mathrm{C}\right)$

$\theta_{c}, \theta_{\infty}:$ 液温と地中平均温度 $\left({ }^{\circ} \mathrm{C}\right)$

$Q:$ 蒸発量 $\left(\mathrm{kcal} / \mathrm{m}^{2} \mathrm{~h}\right)$

$t_{0}, t:$ 時 間 (h)

とすると次の結果を得る。

a) $0 \leq t \leq t_{0}$ のとき

$$
\begin{aligned}
\frac{\theta_{1}-\theta_{\infty}}{\theta_{c}-\theta_{\infty}}= & \frac{t}{t_{0}} \sum_{n=0}^{\infty}\left\{\alpha^{n} 4 i^{2} \operatorname{erfc} \frac{(2 n+1) l+x}{2 \sqrt{\kappa_{1} t}}\right. \\
& \left.-\alpha^{n+1} 4 i^{2} \operatorname{erfc} \frac{(2 n+1) l-x}{2 \sqrt{\kappa_{1} t}}\right\} \cdots
\end{aligned}
$$

$\frac{\theta_{2}-\theta_{\infty}}{\theta_{c}-\theta_{\infty}}=\frac{2}{1+\sigma} \frac{t}{t_{0}} \sum_{n=0}^{\infty} \alpha^{n} 4 i^{2} \operatorname{erfc} \frac{(2 n+1) l+k x}{2 \sqrt{\kappa_{1} t}}$

$$
\begin{aligned}
\frac{Q l}{K_{1}\left(\theta_{c}-\theta_{\infty}\right)} \cong-\frac{l}{\sqrt{\kappa_{1} t}} \frac{t}{t_{0}} \\
\cdot\left\{\frac{2}{\sqrt{\pi}}+2 \sum_{n=1}^{\infty} \alpha^{n} 2 i \operatorname{erfc} \frac{n l}{\sqrt{\kappa_{1} t}}\right\}
\end{aligned}
$$

b) $t \geq t_{0}$ のとき

$$
\begin{aligned}
\frac{\theta_{1}-\theta_{\infty}}{\theta_{c}-\theta_{\infty}}= & \frac{t}{t_{0}} \sum_{n=0}^{\infty} \alpha^{n}\left\{4 i^{2} \operatorname{erfc} \frac{(2 n+1) l+x}{2 \sqrt{\kappa_{1} t}}\right. \\
& \left.-\alpha 4 l^{2} \operatorname{erfc} \frac{(2 n+1) l-x}{2 \sqrt{\kappa_{1} t}}\right\} \\
& +\frac{t-t_{0}}{t_{0}} \sum_{n=0}^{\infty} \alpha^{n}\left\{\alpha 4 i^{2} \operatorname{erfc} \frac{(2 n+1) l-x}{2 \sqrt{\kappa_{1}\left(t-t_{0}\right)}}\right. \\
& \left.-4 i^{2} \operatorname{erfc} \frac{(2 n+1) l+x}{2 \sqrt{\kappa_{1}\left(t-t_{0}\right)}}\right\} \cdots \cdots \cdots(4) \\
\frac{\theta_{2}-\theta_{\infty}}{\theta_{c}-\theta_{\infty}}= & \frac{2}{1+\sigma}\left\{\frac{t}{t_{0}} \sum_{n=0}^{\infty} \alpha^{n} 4 i^{2} \operatorname{erfc} \frac{(2 n+1) l+k x}{2 \sqrt{\kappa_{1} t}}\right. \\
& \left.-\frac{t-t_{0}}{t_{0}} \sum_{n=0}^{\infty} \alpha^{n} 4 i^{2} \operatorname{erfc} \frac{(2 n+1) l+k x}{2 \sqrt{\kappa_{1}\left(t-t_{0}\right)}}\right\}
\end{aligned}
$$

$$
\begin{aligned}
\frac{Q l}{K_{1}\left(\theta_{c}-\theta_{\infty}\right)} \cong \frac{t-t_{0}}{t_{0}} \frac{l}{\sqrt{\kappa_{1}\left(t-t_{0}\right)}} \\
\cdot\left\{\frac{2}{\sqrt{\pi}}+2 \sum_{n=1}^{\infty} \alpha^{n} 2 i \operatorname{erfc} \frac{n l}{\sqrt{\kappa_{1}\left(t-t_{0}\right)}}\right\} \\
-\frac{t}{t_{0}} \frac{l}{\sqrt{\kappa_{1} t}}\left\{\frac{2}{\sqrt{\pi}}+2 \sum_{n=1}^{\infty} \alpha^{n} 2 i \operatorname{erfc} \frac{n l}{\sqrt{\kappa_{1} t}}\right\}
\end{aligned}
$$

ただし

$$
\begin{aligned}
& k^{2}=\frac{\kappa_{1}}{\kappa_{2}} \quad \sigma=\frac{K_{2}}{K_{1}} k \quad \alpha=\frac{\sigma-1}{\sigma+1} \\
& \operatorname{erfc}(X)=1-\operatorname{erf}(X)=1-\frac{2}{\sqrt{\pi}} \int_{0}^{X} e^{-t^{2}} d t
\end{aligned}
$$

$i \operatorname{erfc}(X)=\frac{1}{\sqrt{\pi}} e^{-X^{2}}-X \operatorname{erfc}(X)$

$4 i^{2} \operatorname{erfc}(X)=\left(1+2 X^{2}\right) \operatorname{erfc}(X)-\frac{2 X}{\sqrt{\pi}} e^{-X^{2}}$

\section{（2）一次元近似計算の係数補正方法}

これまでの著者らの近似計算方法は計算を簡略にする ために，一次元で，かつ凍土の潜熱を 0 とし，土の熱的 性質は凍結しても変化しないものと仮定して計算してい る。このために凍結深度を例にとると，ある時期からは 実験值よりも計算值の方が大きくなる傾向にある。この 時期を近似計算適用限とすればこの適用限はタンクの半 径 $R$ の関数になっていることが想像される。また土が 凍るとその熱伝導率は凍結前にくらべて 5 10 割増加す る。そこでまず凍結による熱伝導率などの変化が凍結深 度に与える影響を考える。文献 4）の図一7によると， これまでの著者らの計算と同じょうに凍結潜熱を 0 と し, 凍土の温度伝導率も凍結前のそれに等しいと仮定し て計算したものが一次元の厳密解に最も近い。この時の 厳密解に対する誤差の割合は 17 27\% の間にあって非 常に小さいことがわかる。しかしながらこの文献にも記 されているように，このようなことは実際の円管冷却の 場合には必ずしも成立しない。著者らの各種の模型実験 によると, 上記豲密解は実験值の数倍から 10 倍度大き くなり，しかもタンクの径が小さいものほど大きくな る。このことは土の熱的性質よりもタンクの径が凍結深 度に大きく影響を与えていることを物語っている。そこ で著者らはタンクの径の影響を含む実験式を求めた。す なわち次に述べるように，実際に式 (1) 式 (6) を数值 計算する際に凍る前の土の熱伝導率（または 温 度 伝 導

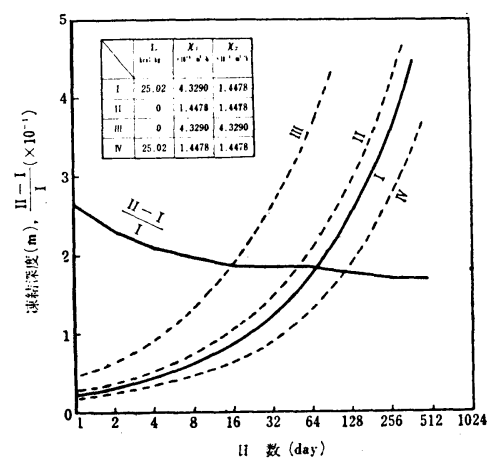

図一7 シートパイルの凍結曲線4) 
率）に補正係数を乗じた見かけの熱伝導率を用いると実 験值に近い值が得られた。

一般に, 模型実験を行なうとき, タンクの半径, 凍結 前の土の温度伝導率および時間をそれぞれ $R_{0}, \kappa_{0}, t_{0}$ と し，実物の時のそれらをそれぞれ $R, \kappa ， t$ とすると， 模型実験の結果から実物の結果を推定する場合には, 次 式のように両方の Fourier Number を等しくするよう に時間を Scale up する。

$$
\frac{\kappa_{0} t_{0}}{R_{0}{ }^{2}}=\frac{\kappa t}{R^{2}}
$$

土の密度 $\rho_{0}, \rho$, 比熱 $c_{0}, c$, 熱伝導率 $K_{0}, K$, そして 温度伝導率 $\kappa_{0}, \kappa$ との間には次のような関係がある。

$$
K_{0}=\kappa_{0} c_{0} \rho_{0}, K=\kappa c \rho
$$

式（12）を式（11）に代入すれば次式を得る。

$$
\frac{K}{K_{0}}=\frac{c \rho}{c_{0} \rho_{0}} \frac{t_{0}}{R_{0}^{2}} \frac{R^{2}}{t}=c^{\prime} \frac{R^{2}}{t} \cdots
$$

$$
\text { ただし, } c^{\prime}=\frac{c \rho}{c_{0} \rho_{0}} \frac{t_{0}}{R_{0}{ }^{2}}
$$

見かけの熱伝導率を用いるといらことは，実際のそれ よりも小さく見積った值を用いることであって，この小 さく見積る割合は, 実験結果からみるとタンクの半径の 二乗に比例し, 適用限 (時間) に逆比例すると推定でき る。そこで

$K_{2}$ : 数値計算に用いる未凍結土の熱伝導率（見か けの熱伝導率)

$K_{20}:$ 未凍結土の実際の熱伝導率（測定值）

$$
\begin{gathered}
R: \text { 実物のタンクの半径 } \\
t: \text { 適用限 (時間) }
\end{gathered}
$$

として，これらの係数および変数の間に式 (13) と同じ 関係があるものと仮定する。すなわち

$$
0<\frac{K_{2}}{K_{20}}=C^{\prime} \frac{R^{2}}{t} \leqslant 1.0
$$

ここで $C^{\prime}$ は実験的に求められる倸数であって, 著者 らの実験からは $C^{\prime} \cong \frac{1000}{3} \mathrm{~h} / \mathrm{m}^{2}$ となる。

このように式（15）によって係数を補正したものを式 (1)〜(10) に入れて数值計算すれば，一次元の計算では あるが，ある程度半径の影響や凍土の潜熱の影響を加味 した実験と良く合う計算值が得られる。

これまでに著者らが数々の模型タンクについてドライ アイス, $\mathrm{LN}_{2}$, LPG を使って冷却して得られた凍結深 度の実験值および係数補正法によって得られた計算值を 図一8 から図一10に，またこれらの係数補正の様子を 表一3 に示す。以上のことから, 低温タンクの寸法およ び土質が変わっても, タンク構成部材および土の非定常 状態における熱現象を定量的に推定するのに，この係数 補正法を併用すれば一次元の近似式でもかなり実用しう ることがわかった。

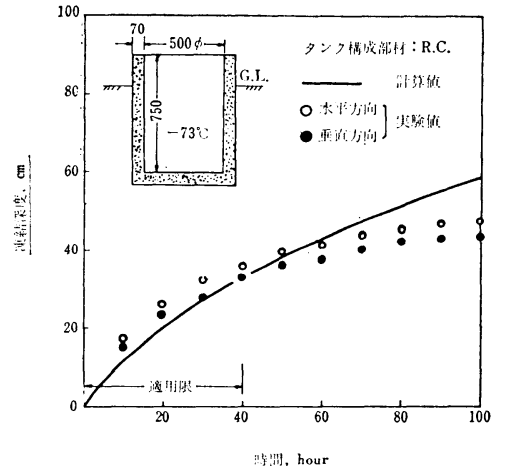

図一8 ドライアイスによる模型タンクの 凍結深度の計算值と実験值

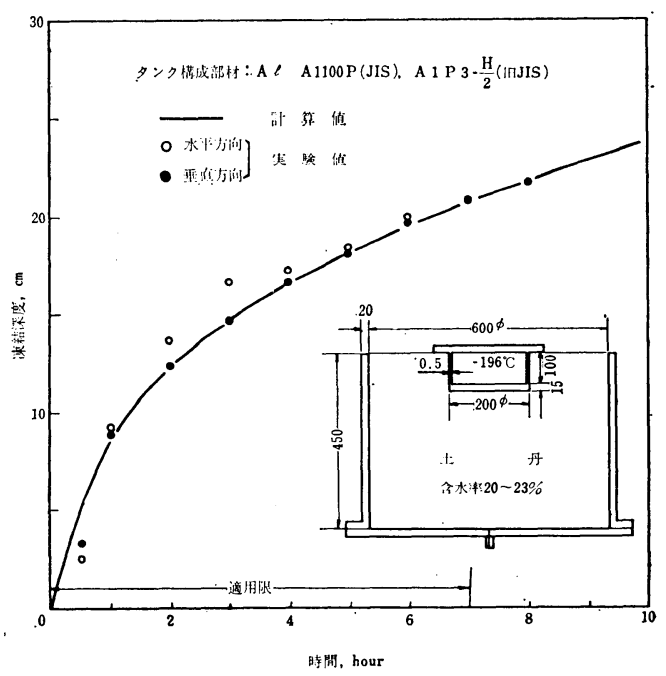

図一9液体窒素による模型タンクの 凍結深度の計算值と実験值

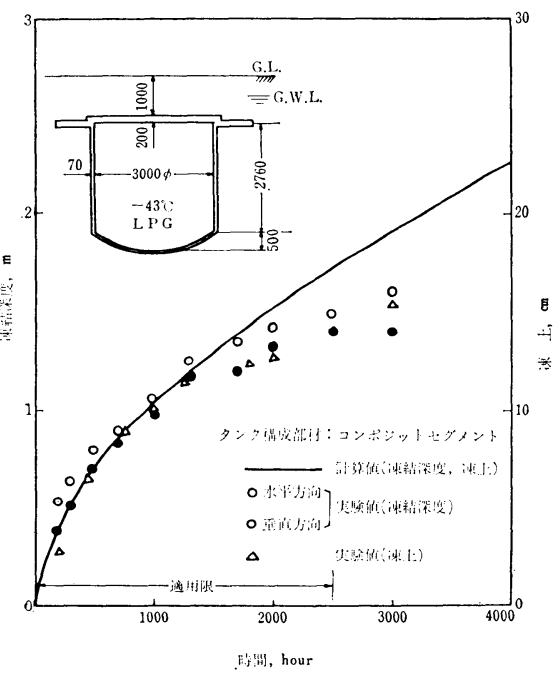

図一10 $20 \mathrm{~m}^{3}$ LPG 地下タンクの凍結深度と 凍上の計算值と実験值 
表一3 係 数 補 正一筧表

\begin{tabular}{|c|c|c|c|c|c|c|c|c|c|c|}
\hline $\begin{array}{c}\text { タンクסilitit. } \\
2 \mathrm{R} \\
\mathrm{mm}\end{array}$ & $\begin{array}{l}\text { 深 } \\
\mathrm{H}\end{array}$ & $\begin{array}{ll}\text { 笵 } & \text { 沙 } \\
\theta \mathrm{c} & \mathrm{C}\end{array}$ & 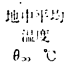 & 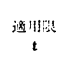 & 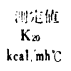 & 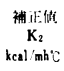 & $\frac{\mathrm{K}_{2}}{\bar{K}_{30}}$ & $\frac{\frac{\mathrm{R}^{2}}{\mathrm{t}}}{\times 10^{-2} \mathrm{~m}^{2} / \mathrm{h}}$ & $\frac{2 \mathrm{R}}{\mathrm{H}}$ & $\begin{array}{l}\text { タンク满吸 } \\
\text { 主: 要部板 }\end{array}$ \\
\hline $200 \phi$ & $\begin{array}{c}100 \\
\& \\
200\end{array}$ & $\begin{array}{l}-196 \\
\left(L . N_{2}\right)\end{array}$ & 20 & $7^{1 \times x}$ & 1.890 & 0.900 & 0.48 & 1.43 & $\begin{array}{l}1.0 \\
\& \\
2.0\end{array}$ & A $f: A 1100 \mathrm{P}$ \\
\hline $500 \%$ & 750 & -72 & 15 & $40^{-\cdots n}$ & 1.920 & 1.000 & 0.52 & 1.56 & 0.67 & R.C. \\
\hline $\begin{array}{l}3,000,5 \\
\left(20 \mathrm{~m}^{2}\right)\end{array}$ & 3250 & $\begin{array}{l}-43 \\
(\mathrm{LPG})\end{array}$ & 17 & $2500^{1 / x}$ & 1.500 & 0.450 & 0.30 & 0.90 & 0.92 & 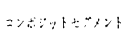 \\
\hline $\begin{array}{l}60.000 \mathrm{~s} \\
\left(10 \mathrm{jm}^{3}\right)\end{array}$ & 39,000 & $\begin{array}{c}-163 \\
(\mathrm{~L} N \mathrm{C})\end{array}$ & 17 & $70^{1+4 x}$ & 1.700 & 0.834 & 0.49 & 1.49 & 1.54 & $\begin{array}{c}=:+i p t+y+t \\
\& \\
R . C .\end{array}$ \\
\hline
\end{tabular}

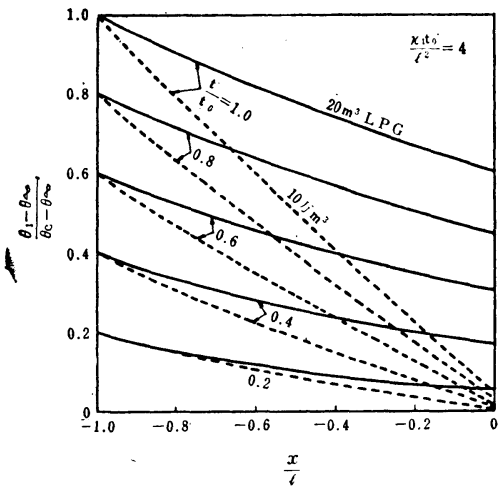

图一12 第 1 周内の温度分布 $\left(\kappa_{1} t_{0} / l^{2}=4\right)$

なお適用限を越えると計算值の方が当然大きくなる が，図一23 に示すようにこの適用限は最終の非定常状 態に近いものであると考えられるので, 大型地下タンク の場合には適用限はタンクの耐用年数よりも大きくなる こともある。これまでの実験から $R^{2} / t$ の目安として $(1.0 \sim 2.0) \times 10^{-3} \mathrm{~m}^{2} / \mathrm{h}$ の範囲で係数補正を行なえば好 結果が得られる。

係数補正法を併用して低温タンクの構成部材および土 内の温度分布について数值計算した結果を図一12～図一 16 に示す。これらの図は $20 \mathrm{~m}^{3} \mathrm{LPG}$ 地下タンクの場 合を実線で, また後述するように 10 万 $\mathrm{m}^{3} \mathrm{LNG}$ 地下タ ンクの場合を点線で示す。したがって図-10の凍結深 度の計算值は図一15 の実線から算出したものである。 同様に $20 \mathrm{~m}^{3} \mathrm{LPG}$ と 10 万 $\mathrm{m}^{3} \mathrm{LNG}$ 地下タンクの蒸 発量の計算値を図一17 に，また $20 \mathrm{~m}^{3} \mathrm{LPG}$ 地下タン クの場合の計算值と実験值の比較を図一18 に示す。図 -10 と図-18 に示す $20 \mathrm{~m}^{3}$ LPG 地下タンクの凍結深 度と蒸発量の実験值と計算值を比較してみると適用限の

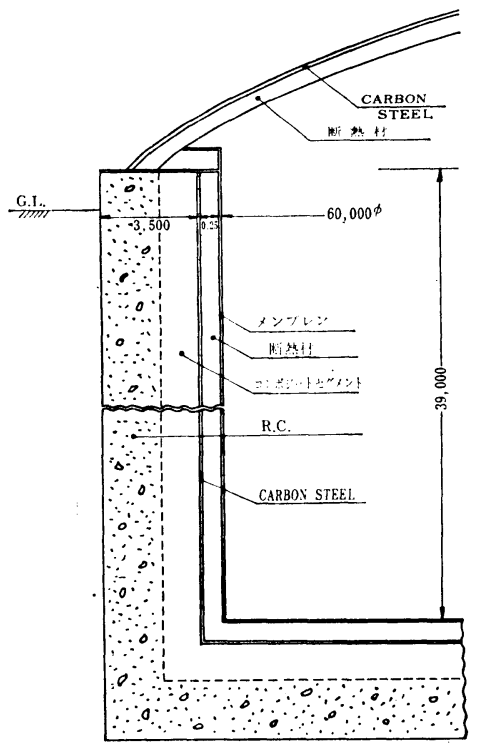

図一11 10 万 $\mathrm{m}^{3}$ 低温地下タンク

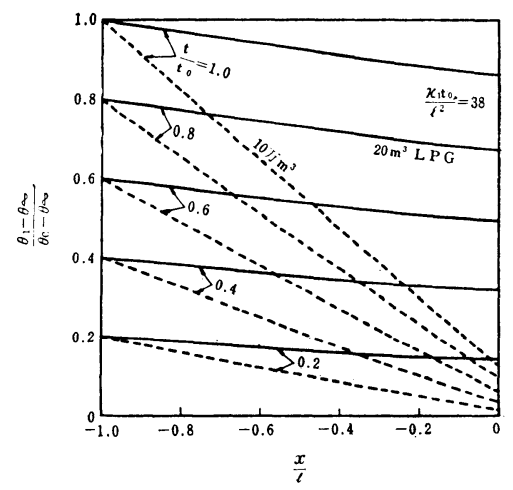

図一13 第 1 屈内の温度分布 $\left(\kappa_{1} t_{0} / l^{2}=38\right)$

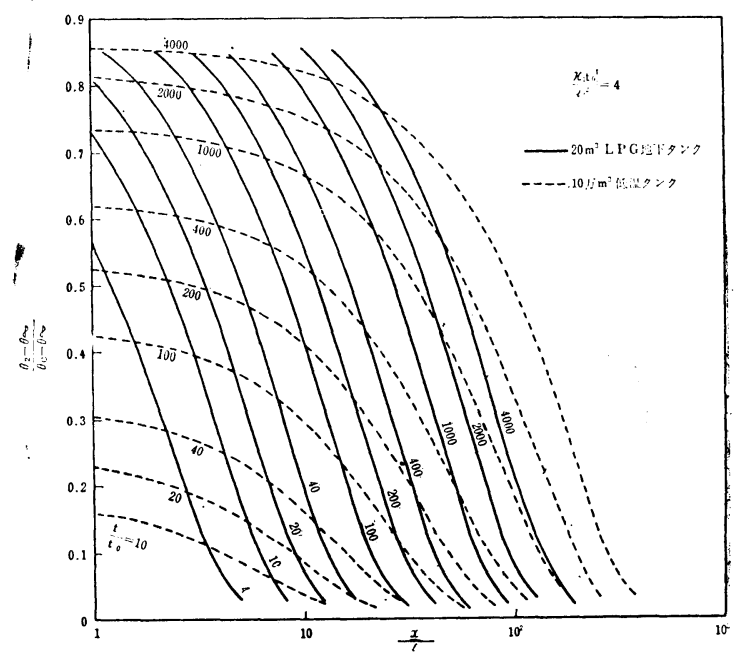

图一14第 2 居内の温度分布 $\left(\kappa_{1} t_{0} / l^{2}=4\right)$

近傍までは両者が良く合っているので，次に係数補正法 を併用して大型の低温地下タンクの熱現象を定量的に推. 定する。

\section{（3）大型低温地下タンクへの適用}

近年増加しつつある LPG, LNG の需要を満たすため 


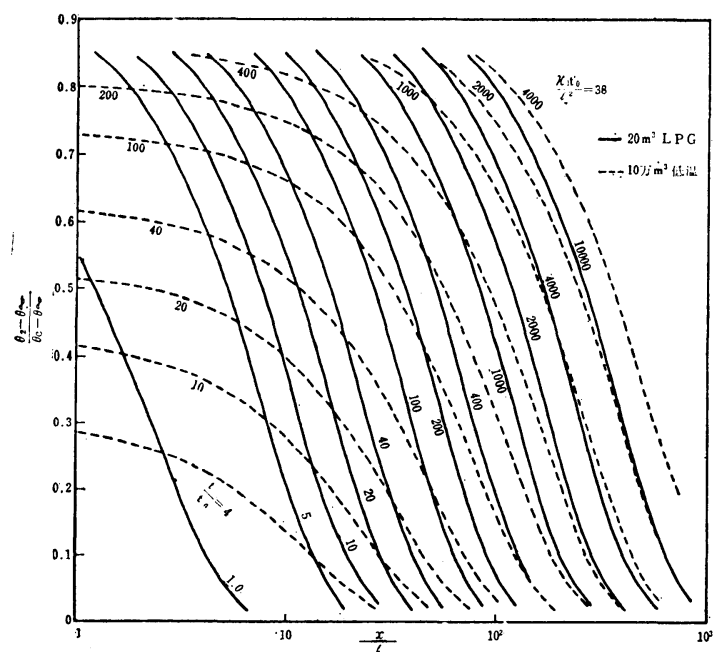

図-15 第 2 酮内の温度分布 $\left(\kappa_{1} t_{0} / l^{2}=38\right)$

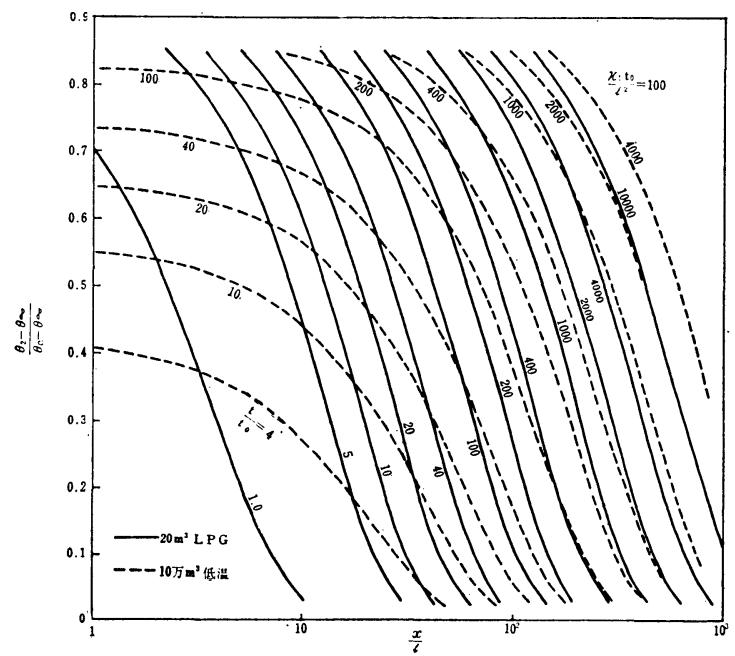

図一16 第 2 届内の温度分布 $\left(\kappa_{1} t_{0} / l^{2}=100\right)$

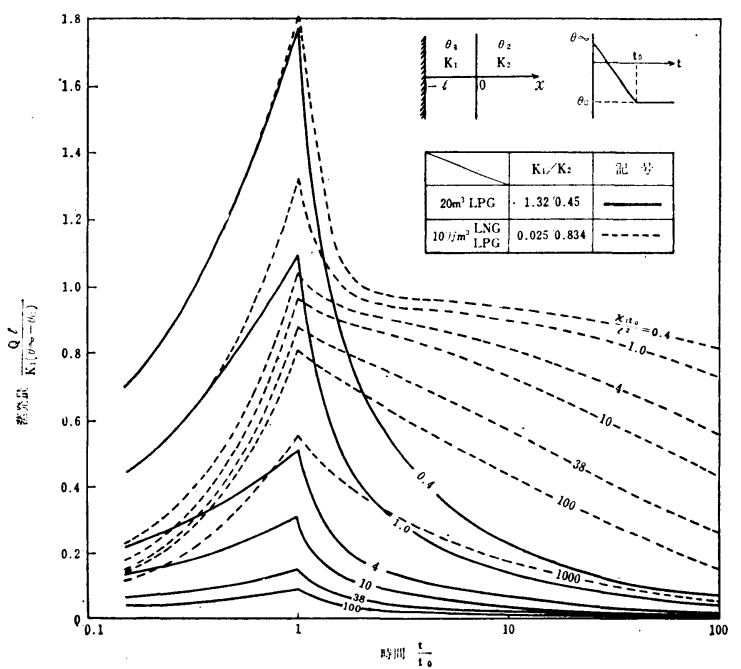

図一17蒸発量と時間の計算值

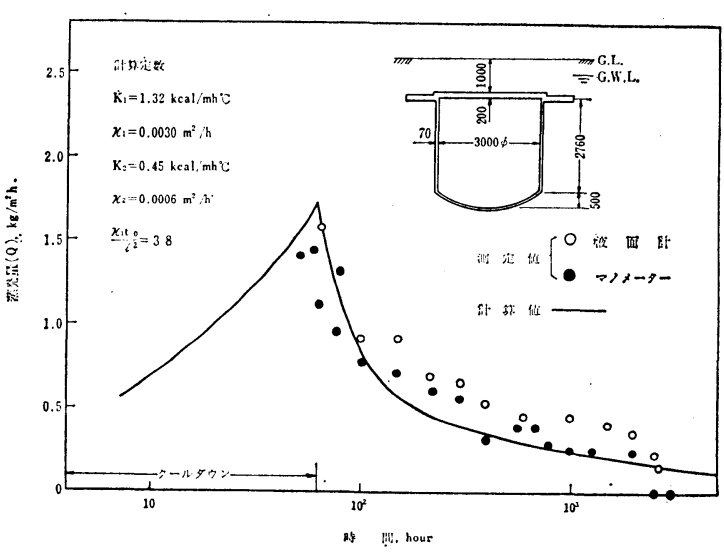

図一18 $20 \mathrm{~m}^{2}$ LPG 地下タンクの蒸発贯の 計算值と実験值の比較

と地下タンクの特性を生かすためには数万 $\mathrm{m}^{3}$ 以上の大 型地下タンクの建設が望ましい。実際に大型の地下タン クを建設する場合は使用条件, 立地条件等によってタン クの形状および寸法は多少異なってくるであろうが，図 -11 に示す 10 万 $\mathrm{m}^{3}$ 低温地下タンクを想定して，こ のタンクに LPG, LNG を貯蔵する場合の熱現象を定 量的に推定する。

a) 10 万 $\mathrm{m}^{3}$ 低温地下タンクの主な仕様と物性值 タンク内径 $D=60 \mathrm{~m}$ タンク深さ $H=39 \mathrm{~m}$ 断熱材厚さ $l=0.25 \mathrm{~m}$ 側壁厚さ $3.5 \mathrm{~m}$ 断熱材の物性值 $K_{1}=0.025 \mathrm{kcal} / \mathrm{mh}^{\circ} \mathrm{C}$

$$
\kappa_{1}=1.04 \times 10^{-3} \mathrm{~m}^{2} / \mathrm{h}
$$

末凍結土の熱伝導率 $K_{20}=1.700 \mathrm{kcal} / \mathrm{mh}^{\circ} \mathrm{C}$ 未凍結土の見かけの熱伝導率 $K_{2}=0.834 \mathrm{kcal} / \mathrm{mh}^{\circ} \mathrm{C}$ LNG, LPG の密度 $\rho_{N}=430 \mathrm{~kg} / \mathrm{m}^{3}$

$$
\text { LNG, LPG の潜熱 } \begin{aligned}
L_{N}=120 \mathrm{kcal} / \mathrm{kg} \\
L_{P}=100 \mathrm{kcal} / \mathrm{kg}
\end{aligned}
$$

クールダウンに要する時間 $t_{0}=240 \mathrm{~h}$

b) 計算結果

a）の仕様と物性值を用いて式 (1)，(2)，(4), (5)より 断熱材と土の温度分布について数值計算した結果の一部 を図-12〜図-16 の点線にて示す。そこで 10 万 $\mathrm{m}^{3}$ 地 下タンクの場合には $\kappa_{1} t_{0} / l^{2}=4$ であるので図一12 の点 線より断熱材内の温度分布を, また図一14の点線より 土の温度分布と凍結深度を算出することができる。その 結果, 図一19 に凍結深度を, 図一20 にはコンクリート 内外壁の温度変化および温度差を示す。図一20より内 外壁の温度差が 最大となるのは $1.0 \sim 1.5$ 年後で, そ の值は $\mathrm{LNG}$ の場合は $40^{\circ} \mathrm{C}, \mathrm{LPG}$ の場合は $13^{\circ} \mathrm{C}$ であ る。ここでコンクリートの温度分布の計算に際しては, 地下水を含むコンクリートの物性値は土のそれに等しい 
と仮定した。

次に式 (3) と（6）より計算した蒸発量の無次元化し たものを図一17 の点線にて示す。同図より最大貯蔵量 $\left(10\right.$ 万 $\left.\mathrm{m}^{3}\right)$ に対する 1 日当りの蒸発量を算出したもの

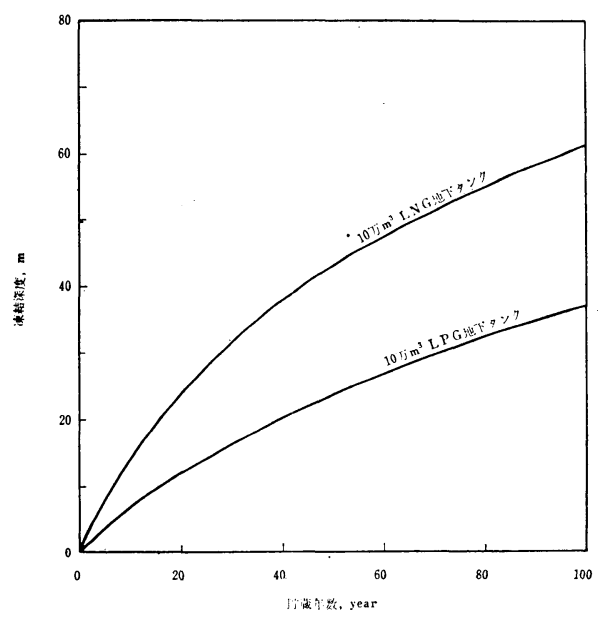

図一19 10 万 $\mathrm{m}^{3}$ 低温地下タンクの凍結深度
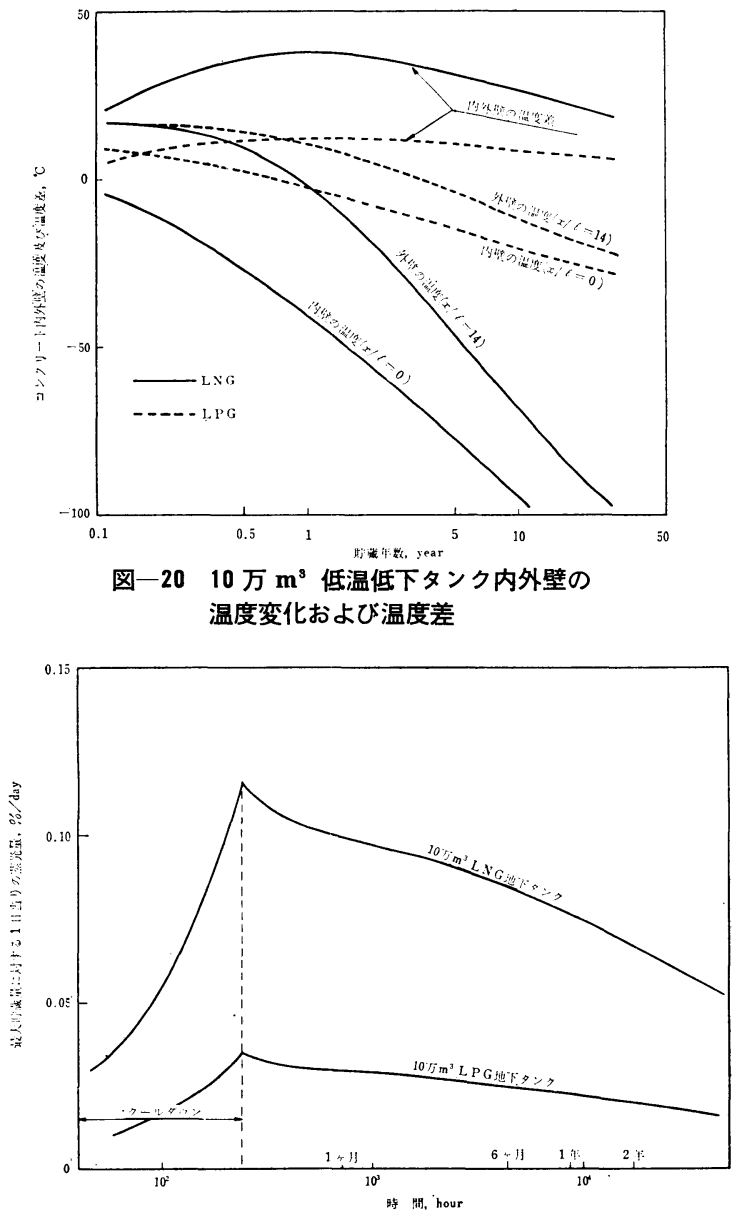

図一21 10 万 $\mathrm{m}^{8}$ 低温地下タンクの蒸発
が 図一21 である。一般に地下タンクの蒸発量は冷却初 期において二重殼式の地上タンクのそれよりも大きくな るが，この LNG 地下タンクの場合は最大 $0.116 \% /$ day となって, 地上タンクにくらべて同等をたはそれ以上の 性能を期待することができる。LPG 地下タンクの場合 は 0.035\%/day となって非常に小さいが，これは図一11 のタンクの仕様と寸法が LNG を対象に考えられている ためである。実際の LPG タンクの場合は断熱材の厚さ を $0.25 \mathrm{~m}$ から $0.10 \mathrm{~m}$ 程度にすると, 地上タンクの性 能に匹敵してくる。図一17，図一21 から明らかなよう に蒸発量はクールダウン終了時, すなわち $t / t_{0}=1$ の時 に最大值を示す。そしてこの最大蒸発量はタンクの容量 に大きく依存する。LNG の場合についてこの依存性を 示したのが図一22 である。同図では $D / H=1.54$ の相 似のタンクで比較しているが，数万 $\mathrm{m}^{3}$ 以上の大型地下

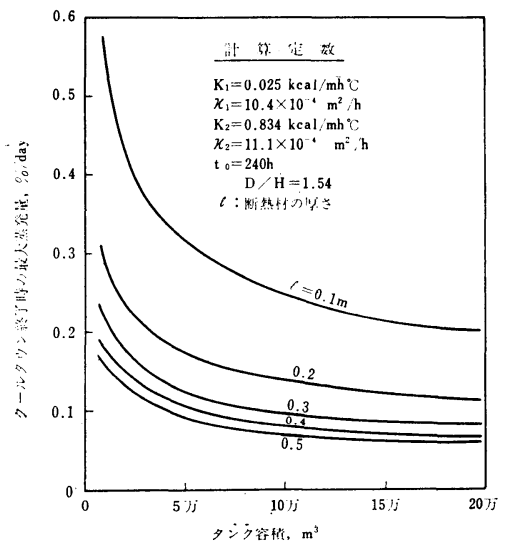

図一22 LNG 地下タンクの容積および断熱材の 厚さと最大蒸発贯の関係

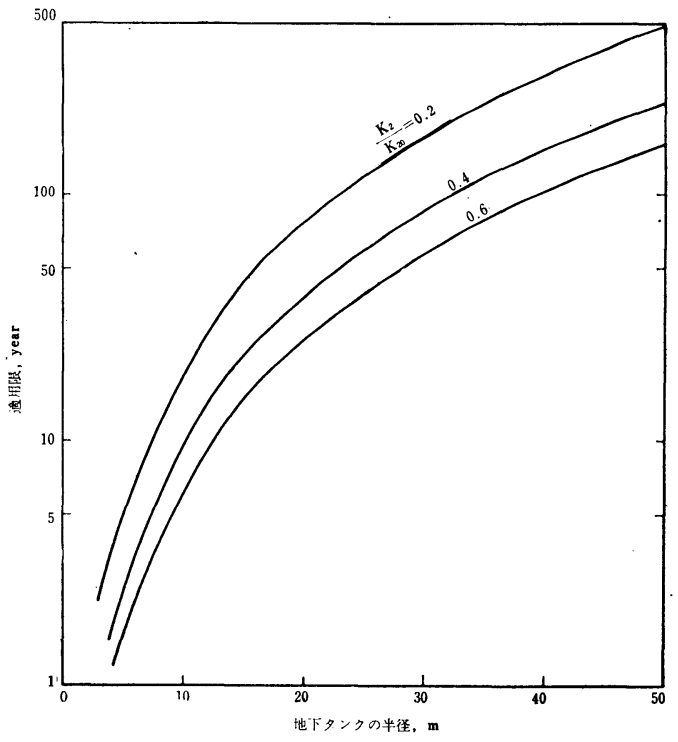

図一23 地下タンクの半径と適用限の関係 
タンクが熱量的に経済的であることが認められる。さら に直径と深さの比が 1 であるものが熱量的には経済的で あることは明白である。図一12 図一17には $20 \mathrm{~m}^{3}$ と 10 万 $\mathrm{m}^{3}$ のタンクの温度分布と蒸発量を無次元化して 示したものであるが，タンク構成部材とそのまわりの土 の熱物性值が同じであれば LPG，LNG にかかわりな く、いかなる寸法の地下タンクの熱現象にもこれらのグ ラフを適用できる。

$20 \mathrm{~m}^{3} \mathrm{LPG}$ 地下タンクの場合には凍上量は凍結哚度に ほぼ比例している。凍上量を理論的に解析するのはむず かしいので目安として次のように考えることもできる。

$Y=A X_{0}$

$Y:$ 凍上量

$A:$ 実験によって求める凍上率 (定数)

$X_{0}$ : 式 (5) 上り計算される凍結深度で式 (17) を 満足する。

$$
\begin{aligned}
\frac{\theta_{\infty}}{\theta_{\infty}-\theta_{c}}= & \frac{2}{1+\sigma}\left\{\frac{t}{t_{0}} \sum_{n=0}^{\infty} \alpha^{n} 4 i^{2} \operatorname{erfc} \frac{(2 n+1) l+k X_{0}}{2 \sqrt{\kappa_{1} t}}\right. \\
& \left.-\frac{t-t_{0}}{t_{0}} \sum_{n=0}^{\infty} \alpha^{n} 4 i^{2} \operatorname{erfc} \frac{(2 n+1) l+k X_{0}}{2 \sqrt{\kappa_{1}\left(t-t_{0}\right)}}\right\}
\end{aligned}
$$

$20 \mathrm{~m}^{3}$ LPG 地下タンクの埋設部のような軟弱シルト で, 上載荷重が $0.01 \mathrm{~kg} / \mathrm{cm}^{2}$ の場合は $A \cong 0.10$ であ ったが，土質および地下水位によっては 0.01 0.30ぐ らいまでの値をとることが経験された。

\section{7. 結論}

（1）これまでの経験からみて，粘土質で地下水位が 低、場合はウェルポイントを使わず，セグメント工法の みで $-10 \sim-15 \mathrm{~m}$ 程度まで掘削および組立ては可能で あるが，今回のように地下水位が高く，軟弱シルトの場
合には水の処理に困難がある。この LPG タンクは小さ かったので問題も比較的少なかったが，大型タンクの場 合はセグメント工法を助ける仮設工法が必要である。立 地条件の制約からセグメントの接合には溶接が使用でき ず，防水剂とエポキシ系接着材を用いたが初期の目的を 達した。

（2）本実験では短期間に変化の激しい熱現象を観察 するために，タンクに断熱材を取付けずに冷却と貯蔵を 行なったが, 熱応力, 凍結土圧, 凍上によるタンクの破 境，倒壊はなかった。凍上率は約 $10 \%$ で，凍上は最大 $15 \mathrm{~cm}$ を記録したが, 凍結土圧は無視できる程度の值で あった。また蒸発量はクールダウン終了時最大 $1.6 \mathrm{~kg} /$ $\mathrm{m}^{2} \mathrm{~h}$ であった。実際の低温地下タンクには断熱材を付け るのでこれらの值はもっと小さくなるはずである。

(3) $20 \mathrm{~m}^{3} \mathrm{LPG}$ 地下タンクにおける熱現象の計測 值と, 係数補正法による一次元の計算值はほぼ一致する ことがわかったので, 大型の 10 万 $\mathrm{m}^{3}$ 低温地下タンク の熱現象を定量的に推定した。

最後に本実験を遂行するにあたっては，東京ガス(株) と石川島播磨重工業 (株) 両社, 多数の関係者および矢 田博士のご協力を得ました。ここに謝意を表する次第で あります。

\section{参 考 文 献}

1）秋田好雄ほか：コンポジットシェルュニットの開発によ せて, 石川島播磨技報, 第 8 巻第 42 号, 昭和 43 年 7 月

2）秋田好雄・矢田敏夫・柳沢一郎 : 低温液体貯蔵地下タン ク関する基礎的研究，土木学会論文集，第 157 号，昭 和 43 年 9 月

3）秋田好雄・矢田敏夫・柳沢一郎：コンポジットセグメン 卜製低温液化ガス貯蔵用地下タンクに関する基礎的考察, 石川島播磨技報, 第 8 巻第 43 号, 昭和 43 年 9 月

4）高志 勤-和田正八郎：土壌谏結工法 [1], 冷谏 36 巻 408 号

(1971.7.6 - 受付) 